\title{
Detection of transgenic cp4 epsps genes in the soil food web
}

\author{
Miranda M. HART ${ }^{1}$, Jeff R. PowelL ${ }^{1}$, Robert H. GuLdEN ${ }^{2}$, David J. LEVY-BOOTH ${ }^{3}$, Kari E. DunFIELD ${ }^{4}$, \\ K. Peter PAUls ${ }^{2}$, Clarence J. SwANTON ${ }^{2}$, John N. KLIRONOMOs ${ }^{1}$, Jack T. TreVORS ${ }^{3}$ \\ ${ }^{1}$ Department of Integrative Biology, University of Guelph, Guelph, Ontario, N1G 2W1, Canada \\ ${ }^{2}$ Department of Plant Agriculture, University of Guelph, Guelph, Ontario, N1G 2W1, Canada \\ ${ }^{3}$ Department of Environmental Biology, University of Guelph, Guelph, Ontario, N1G 2W1, Canada \\ ${ }^{4}$ Department of Land Resource Science, University of Guelph, Guelph, Ontario, N1G 2W1, Canada
}

(Accepted 12 May 2009)

\begin{abstract}
The persistence and movement of transgenic DNA in agricultural and natural systems is largely unknown. This movement poses a threat of horizontal gene transfer and possible proliferation of genetically modified DNA into the general environment. To assess the persistence of transgenic DNA in a field of Roundup Ready ${ }^{\circledR}$ corn, we quantified the presence of the transgene for glyphosate tolerance within a soil food web. Using quantitative real-time PCR, we identified the cp4 epsps transgene in bulk soil microarthropods, nematodes, macroarthropods and earthworms sampled within the corn cropping system. We found evidence of the transgene at all dates and in all animal groups. Transgenic DNA concentration in animal was significantly higher than that of background soil, suggesting the animals were feeding directly on transgenic plant material. It remains to be tested whether this DNA was still within the plant residues, present as free, extracellular DNA or had already undergone genetic transformation into competent bacterial cells. These results are the first to demonstrate the persistence of transgenic crop DNA residues within a food web.
\end{abstract}

agriculture / DNA / environment / corn / foodweb / glyphosate / soil / transgenic

\section{INTRODUCTION}

The movement of transgenic DNA in agricultural and natural systems is a growing concern due to the large amounts of DNA entering agricultural systems from transgenic crops (Andow and Zwahlen, 2006). Research demonstrates that transgenes can move beyond the intended organism and into the surrounding environment (Marvier and Van Acker, 2005). This movement poses several risks, such as introgression into natural plant communities (Loureiro et al., 2009) and genetic transformation into natural bacterial populations (deVries and Wackernagel, 2004). Regardless of the mechanism, the movement of transgenes into the environment at large is a real risk, and has serious implications for environmental health, including human safety.

DNA is continuously shed from transgenic plants through root sloughing, pollination, seed dispersal, and senescence (Levy-Booth et al., 2007). A potential fate for this DNA is the uptake of transgenes into indigenous microbe populations

*Corresponding author: mhart@uoguelph.ca by natural transformation (Kowalchuk et al., 2003; Heinemann and Traavik, 2004). The soil food web may present a route for the transformation of transgenes into native genetically competent microbial populations as animal digestive tracts, both in vertebrates and invertebrates, may provide conditions ideal for genetic transformation from food residues to gut bacteria (Nielsen et al., 1998). Alternatively, transgenic DNA may be rapidly degraded in the digestive tracts of soil organisms, reducing the persistence of microbial genetic transformation.

For transgenic DNA to be involved in genetic transformation, it must be determined whether it persists in the soil food web. The longevity or $1 / 2$ life of DNA in soil, either naked or within plant residues, is not well known. One study on sugar beets, showed that transgenic nptII genes persisted in soil detectable levels for up to two years (Gebhard and Smalla, 1999).

Currently, it is not known whether transgenic DNA can persist within the dynamic, highly diverse environment of a digestive tract And if so, it remains to be tested how far down the food chain transgenes remain intact. One possibility is that transgenes, while detectable in the soil in plant residues, are undetectable within the food web, either due to such small 
quantities or because the DNA does not persist in a detectable form. Alternatively, transgenes may persist within animals, either as food residue or with transformed gut microbes.

We conducted a preliminary survey of soil invertebrates occurring in a Roundup Ready ${ }^{\circledR}$ cornfield for the presence and quantity of transgenic corn $c p 4$ epsps genes with the goal to identify the location of the transgenes in a soil food web.

\section{MATERIALS AND METHODS}

\subsection{Field study site}

This study was conducted in a field of glyphosate-resistant (Roundup Ready ${ }^{\circledR}$; RR) corn (Zea maize L.) at the Elora Research Station (Elora, ON; 43 ${ }^{\circ} 41^{\prime} \mathrm{N}, 80^{\circ} 26^{\prime} \mathrm{W}$ ) on three occasions (May 2005, August 2005 and October 2005). The field was subject to treatment with Roundup ${ }^{\circledR}$ and conventional herbicides, and was in the third year of continuous cultivation of Roundup Ready crops (corn-soybean (Glycine max L. Merr.) in a two-year rotation). The soil at the Elora Research Station is a Conostogo silt loam soil (sand, 26.1\%; silt, 60.1\%; clay, $13.8 \%$; $\mathrm{pH}, 7.3$; organic matter, $5 \%$; cation exchange capacity, $27.1 \mathrm{cmol} / \mathrm{kg}$ ). The sampled field is part of a larger research project studying the effect of conventional herbicides and Roundup ${ }^{\circledR}$ herbicide on glyphosate resistant versus conventional corn and soybean (Glycine max L. (Merr.)) grown in rotation (Gulden et al., 2008).

\subsection{Organisms}

To assess the pervasiveness of the transgene within the soil food web, we examined four invertebrate groups: microarthropods, nematodes, macroarthropods, and earthworms. Microarthropods and nematodes were sampled in May, August and October 2005, while earthworms and macroarthropods were only sampled on the first two dates due to sample damage. Each group was sampled as follows: on the day of each sampling, 20 soil cores $(10 \mathrm{~cm}$ depth) were obtained at randomly chosen locations in the field and refrigerated until further analysis. Each sample was divided in half for microarthropod and nematode extractions. Microarthropods were extracted using a modified funnel extraction method (Edwards, 1991), identified to order and stored in $70 \%(\mathrm{v} / \mathrm{v})$ ethanol until DNA extraction. Nematodes were extracted into water using a modified funnel extraction method and stored in $70 \%$ ethanol. Macroarthropods were sampled with 10 pit fall traps placed at random within the field the previous night. Captured macroarthopods were isolated, identified to Order, and stored in $70 \%$ ethanol until DNA extraction. At each sample date, eighty earthworms were collected from randomly selected locations within the field. These were preserved in their native soil, at $4{ }^{\circ} \mathrm{C}$ in the dark until further analysis.

\subsection{Transgene}

The transgene in this study was cp 4 epsps specific for corn that confers tolerance to the herbicide glyphosate (Roundup ${ }^{\circledR}$ ).

\subsection{DNA extraction}

Prior to DNA extraction, all organisms were washed and individually preserved in $70 \%$ ethanol. This ensured DNA preservation, and also no adhering soil or plant residue to the organisms. Thus, transgenes, if detected, would be likely from animal guts, not surfaces. For all organisms, we used UltraClean-htp 96-well soil DNA isolation kit (Mo Bio Laboratories, Solana Beach, CA) as per the manufacturer's instructions. For large macroinvertebrates and large earthworms, organisms were first homogenized in a small amount of sterile, distilled water. $100 \mu \mathrm{L}$ of this homogenate was used in DNA extraction.

\subsection{Quantitative real-time PCR}

To determine the presence and quantity of the transgene, we used a method for the quantification of Roundup Ready ${ }^{\circledR}$ corn DNA that was described in Lerat et al. (2005) and Gulden et al. (2005). In brief, we performed quantitative real-time PCR (qPCR) using a molecular beacon and primers specific for corn cp 4 epsps. Detection of the cp 4 epsps used molecular beacons with FAM fluorophores for detection (Lerat et al., 2005). Target DNA was amplified in $20 \mu \mathrm{L}$ total volume (1X iQ Supermix $(50 \mathrm{mM} \mathrm{Kcl}, 20 \mathrm{mM}$ Tris $\mathrm{HCl} \mathrm{pH} 8.4,0.8 \mathrm{mM}$ dNTPs, 0.5 units Taq polymerase, $3 \mathrm{mM} \mathrm{MgCl} 2$ ) (BioRad), $500 \mathrm{nM}$ each forward and reverse primers, $20 \mathrm{ng} / \mu \mathrm{L}$ T4 gene 32 protein, $2 \mu \mathrm{L}$ template DNA, $400 \mathrm{nM}$ Rrmb, sterile water) using an iCycler equipped with iCycler IQ Optical System Software v3.1 (BioRad, Hercules, CA) using 65 cycles of $1 \mathrm{X} 95^{\circ} \mathrm{C}$ for $90 \mathrm{~s}$, and $65 \mathrm{X} 94^{\circ} \mathrm{C}$ for $10 \mathrm{~s}, 53^{\circ} \mathrm{C}$ for $20 \mathrm{~s}$ and $72^{\circ}$ for $30 \mathrm{~s}$. Fluorescence was measured during the $53{ }^{\circ} \mathrm{C}$ annealing cycle.

In addition to conducting qPCR on all invertebrate samples, qPCR was performed on DNA dilution series in water. Ten-fold dilution series of corn genomic and plasmid DNA extract were prepared in ultrapure water. For the generation of standard curves in soil, $10^{1}$ to $10^{8}$ gene copies of target recombinant cp4 epsps were added to $0.25 \mathrm{~g}$ samples from each soil in 96-well bead plates of the Ultra-Clean soil DNA kit (MoBio Laboratories, Solano Beach, CA). Baseline fluorescence data of each qPCR from the ten-fold dilution series in the soils was fitted to one of 5 functions (Fig. 1) to describe the logistic fluorescence curves generated by real-time qPCR. To ensure that all positive samples were not artifacts of the qPCR, only critical threshold $(\mathrm{Ct})$ values below a maximum value of 50 were exported to MS Excel and prepared for further analysis.

\subsection{Data anaylsis}

For each group of animals at each sampling date, we plotted the proportion of individuals positive for the transgene (Fig. 1). We also calculated the mean (and standard deviation) concentration of the transgenic DNA using standard curves generated from threshold cycles during quantitative PCR, using only positive samples below a $\mathrm{Ct}$ of 50 . This was also calculated for each group of animals at each harvest. 


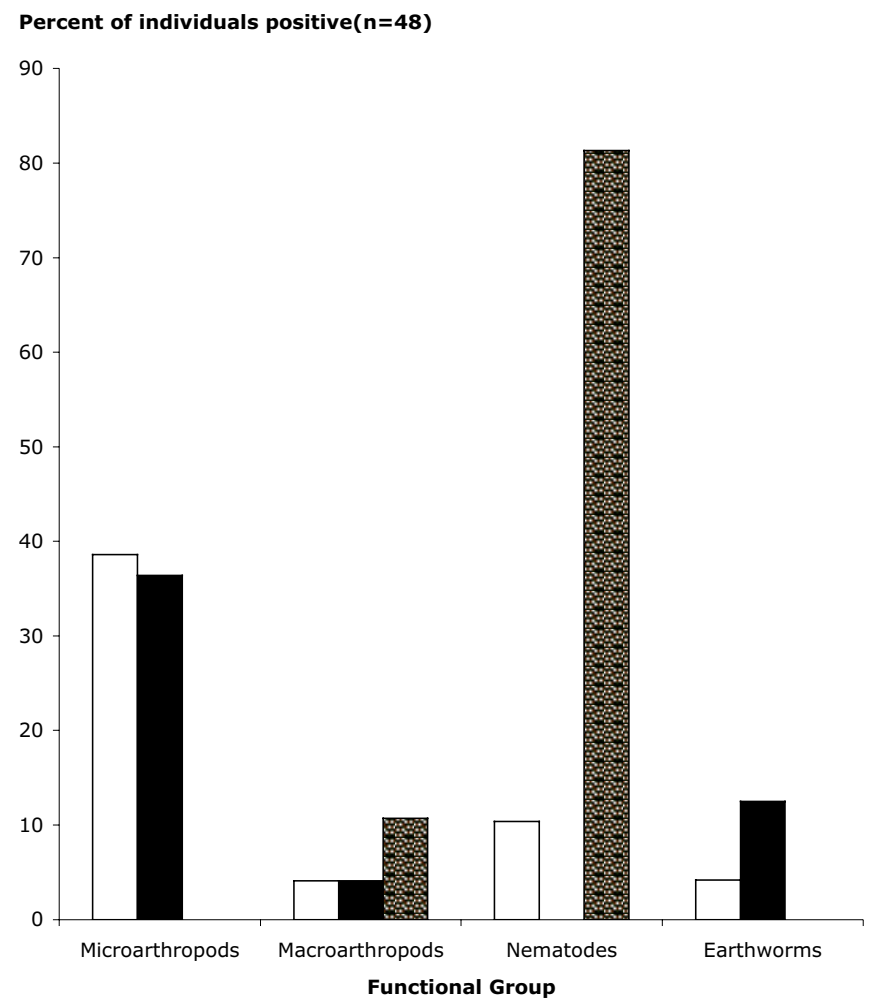

Figure 1. Proportion of individuals positive for cp4 epsps ( $\mathrm{n}=48$ for each functional group, at each harvest). White, black and hatched bars represent May, August and October harvests, respectively. There were neither samples for microarthropods nor earthworms for the October harvest.

\section{RESULTS AND DISCUSSION}

\subsection{Presence and concentration of $c p 4$ epsps in foodweb}

We found evidence of the transgene in all functional groups and at all harvest dates, with the exception of nematodes in August where we detected no transgenes (Fig. 1). Nematodes showed the largest range of positive values, ranging from zero positive individuals in August, to $81 \%$ of individuals testing positive in October. Microarthropods, including thrips, collembolans and mites, had the next greatest occurrence of the transgene, with about $38 \%$ and $36 \%$ of individuals testing positive in May and August, respectively. Macroarthropods, and earthworms, both had fewer positive individuals with maximum values of $11 \%$ and $13 \%$, respectively.

In terms of transgene quantity, values ranged between harvests, between groups, and within groups (Tab. I). Microarthropods contained the least, mean amount of transgenic DNA followed by macroarthropods, nematodes, and earthworms. These data are not surprising, as the difference in body size between the functional groups mean earthworms can hold far more mass in their guts than the other groups. While it is possible that DNA extraction efficiency differs between animal groups, this did not interfere with our ability to detect the gene, even at very low concentrations. We were able to repeatedly amplify cp4 epsps from preserved, single organisms.
Table I. Range of values for concentration of cp4 epsps for each functional group on all harvest dates.

\begin{tabular}{lcc}
\hline Organism & Range of values $(\mathrm{ng} / \mathrm{mL})$ & Mean \pm S.E. $(\mathrm{ng} / \mathrm{mL})$ \\
\hline Microarthropods & $6.5-1160$ & $215.4 \pm 35.7$ \\
Macroarthropods & $8.6-15304$ & $748.2 \pm 44.2$ \\
Nematodes & $7.4-160881$ & $6509 \pm 477$ \\
Earthworms & $18.7-147346$ & $36320 \pm 17590$ \\
\hline
\end{tabular}

In terms of harvest date, DNA concentration in animals decreased progressively throughout the growing season for nematodes and worms, but increased for micro- and macroarthropods (Tab. II). Other studies have shown DNA from litter to release large quantities of DNA in the fall when litter decomposition rates are highest (Levy Booth et al., 2007). While this may explain, in part, the trends we observed with micro- and macro-arthropods, it does not explain the trends observed for nematodes and earthworms. These data fit well with results from other studies conducted at the same site during the same growing season. Gulden et al. (2008) reported that target gene concentration in the soil coincided with active growth stage of the crop (growing season, July/August) (Tab. II).

Further, a related study done at the same site using the same target gene found that DNA flux into the environment was greatest at five days following burial of soy leaf tissue in the soil and decreased over time (Levy Booth et al., 2007). This suggests that there was ample DNA in the environment, either through live plant tissue, or through recently senescing plant material, early in the season.

Background soil target gene concentration (Tab. II) is significantly lower than target gene concentration in the organisms: this suggests that the animals were actively feeding on the genetically modified crop and/or the soil nuclease activity was degrading the DNA in soil. In contrast, the background soil values in Table II did not contain any plant or root material, thus target genes in this portion are likely to be free DNA.

Whether the presence of transgenes in the soil food web presents a risk for soil animals is not known. Many studies have shown no effect on local animal populations exposed to transgenic crops (Donegan et al., 1991; Obryki et al., 2001; Liphadzi et al., 2005) while others have observed changes in faunal group abundances (Brooks et al., 2005; Bohan et al., 2005). However, this risk would depend on the type of crop and product of the transgene in question (Kowalchuk et al., 2003). In the case of glyphosate resistant crops, the risk may be the potential for natural genetic transformation, since the gene is detectable within the soil food web. Whether these genes were naked extracellular DNA, retained within plant residues, or were already transformed into indigenous microbes present within the animals, remains to be determined. Since we looked at short amplicons appropriate for quantitative PCR analysis, it is not known if these fragments of the target gene represent functional genes, or whether the DNA that is in the food web is already in such advanced states of decomposition that it is no longer functional, such as in genetic transformation or able to be transcribed and translated into a functional protein. 
Table II. Average cp4 epsps and standard error for all functional groups per harvest date. Values are given in $\mathrm{ng} / \mathrm{mL}$.

\begin{tabular}{lccccc}
\hline & Microarthropods & Macroarthropods & Nematodes & Worms & Background soil* \\
\hline May & $133 \pm 39$ & 0 & $43000 \pm 29789$ & $98914 \pm 27962$ & $1.56 \times 10^{-9}$ \\
August & $267 \pm 51$ & $9.6 \pm 5.6$ & 0 & $547 \pm 416$ & $3.76 \times 10^{-6}$ \\
October &. & $211 \pm 44$ & $217 \pm 45$ &. & $1.93 \times 10^{-8}$ \\
\hline
\end{tabular}

* Unpublished data from Gulden et al. (2008)

\section{CONCLUSION}

We found evidence for large concentrations of transgenic DNA in animals from the food web associated with RoundUp Ready corn. This indicates that the transgene does not significantly degrade within the food web. Further, the guts of these animals may provide opportunity for genetic transformation into native soil bacteria. It remains to be determined how far down the food web the transgene is detectable and whether or not the identified gene is available for transformation. It may be that animals associated with the soil food web provide an excellent starting spot for detecting genetic transformation in the natural environment.

Acknowledgements: The authors would like to thank Eva Kuczynski, Faye Randall and Eric Peterson for technical assistance. The authors would also like to thank the Natural Sciences and Engineering Research Council of Canada (NSERC), both strategic grants and postdoctoral fellowship (MMH).

\section{REFERENCES}

Andow D.A,. Zwahlen C. (2006) Assessing environmental risks of transgenic plants, Ecol. Lett. 9, 196-214.

Bohan D.A., Boffey C.W.H., Brooks D.R., Clark S.J., Dewar A.M., Firbank L.G., Haughton A.J., Hawes C., Heard M.S., May M.J., Osborne J.L., Perry J.N., Rothery P., Roy D.P., Scott R.J., Squire G.R., Woiwod, I.P. and Champion G.T. (2005) Effects on weed and invertebrate abundance and diversity of herbicide management in genetically modified herbicide-tolerant winter-sown oilseed rape, Proc. R. Soc. B 272, 463-474.

Brooks D.R., Bohan D.A., Champion G.T., Haughton A.J., Hawes C., Heard M.S., Clark S.J., Dewar A.M. , Firbank L.G., Perry J.N., Rothery P., Scott R.J., Woiwod I.P., Birchall C., Skellern M.P., Walker J.H., Baker, P. Bell D., Browne E.L., Dewar A.J.G., Fairfax C.M., Garner, B.H., Haylock L.A., Horne S.L., Hulmes S.E., Mason N.S., Norton L.R., Nuttall P., Randle Z., Rossall M.J., Sands R.J.N., Singer E.J., Walker. M.J. (2005) Invertebrate responses to the management of genetically modified herbicide-tolerant and conventional spring crops. I. Soil-surface-active invertebrates, Philos. T. Roy. Soc. B 358,1847-1862.

de Vries J., Wackernagel W. (2004) Microbial horizontal gene transfer and the DNA release from transgenic crop plants, Plant Soil 226, 91-104.

Donegan K.K., Seidler R.J., Fieland V.J., Schaller D.L., Palm C.J., Ganio L.M., Cardwell D.M., Edwards C.A. (1991) The assessment of populations of soil inhabiting invertebrates, Agr. Ecosyst. Environ. 34, $145-176$.

Edwards C.A. (1991) The assessment of populations of soil inhabiting invertebrates, Agr. Ecosyst. Environ., 145-176.
Gebhard F., Smalla K. (1999) Monitoring field releases of genetically modified sugar beets for persistence of transgenic plant DNA and horizontal gene transfer, FEMS Microbiol. Ecol. 28, 261-272.

Gulden R.H., Lerat, S., Blackshaw, R.E., Powell J.R., Levy Booth D., Dunfield K.E., Trevors J.T., Pauls K.P., Klironomos J.N., Swanton C.J. (2008) Factors affecting the presence and persistence of plant DNA in the soil environment in corn and soybean rotations, Weed Sci. 56, 767-774.

Gulden R.H., Lerat S., Hart M.M., Powell J.R., Trevors J.T., Pauls K.P., Klironomos J.N., Swanton C.J. (2005) Quantitation of transgenic plant DNA in leachate water: Real-time polymerase chain reaction analysis, J. Agr. Food Chem. 53, 5858-5865.

Heinnemann J.A., Traavik T. (2004) Problems in monitoring horizontal gene transfer in field trials of transgenic plants, Nat. Biotechnol. 22, $1105-1110$

Kowalchuk G.A., Bruinsma M., van Veen J.A. (2003) Assessing responses of soil microorganisms to GM plants, Trends Ecol. Evol. $18,403-410$.

Lerat S., England L.S., Vincent M.L., Pauls K.P., Swanton C.J., Klironomos J.N., Trevors J.T. (2005) Real-time polymerase chain reaction (PCR) quantification of the transgenes for Roundup Ready corn and Roundup Ready soybean in soil samples, J. Agr. Food Chem. 53, 1337-1342.

Levy-Booth D.J., Campbell R.G., Gulden R.H., Hart M.M., Powell J.R., Klironomos J.N., Pauls K.P., Swanton C.J., Trevors J.T., Dunfield K.E. (2007) The DNA Cycle in Soil: free DNA in the soil environment, Soil Biol. Biochem. 39, 2977-2991.

Liphadzi K.B.K., Al-Khatib C.N., Bensch P.W., Stahlman J.A., Dille T., Todd C.W., Rice M.J., Horak M.J., Head G. (2005) Soil microbial and nematode communities as affected by glyphosate and tillage practices in a glyphosate-resistant cropping system, Weed Sci. 53, $536-545$.

Loureiro I., Escorial C., Garcia-Baudin J.M., Chueca C. (2009) Hybridization, fertility and herbicide resistance of hybrids between wheat and Aegilops biuncialis, Agron. Sustain. Environ. 29, 237245.

Marvier M., Van Acker R.C. (2005) Can crop transgenes be kept on a leash? Front. Ecol. Environ. 3, 93-100.

Nielsen K.M., Bones A.M., Smalla K., van Elsas J.D. (1998) Horizontal gene transfer from transgenic plants to terrestrial bacteria - a rare event? FEMS Microbiol. Rev. 22, 79-103.

Obryki J.J., Losey J.E., Taylor O.R., Jesse C.C. (2001) Transgenic insecticidal corn: beyond insecticidal toxicity to ecological complexity, Bioscience 51, 353-361.

Steinberger Y. (1997) Decomposition of genetically engineered tobacco under field conditions: persistence of the proteinase inhibitor I product and effects of soil microbial respiration and protozoa, nematode and microarthropod populations, J. Appl. Ecol. 34, 767-777. 
Appendix I. Taxonomic description of microarthropods sampled from the Elora Field Station of the University of Guelph on two dates in 2005. Each number represents one individual that was used for DNA analysis.
Appendix II. Taxonomic description of macroarthropods sampled from the Elora Field Station of the University of Guelph on three dates in 2005. Each number represents one individual that was used for DNA analysis.

\begin{tabular}{|c|c|c|}
\hline & May 2005 & August 2005 \\
\hline 1 & Acariformes & Acariformes \\
\hline 2 & Acariformes & Collembola \\
\hline 3 & Acariformes & Collembola \\
\hline & Collembola & Collembola \\
\hline & Collembola & Acariformes \\
\hline & Collembola & Thysanoptera \\
\hline 7 & Collembola & Collembola \\
\hline 8 & Collembola & Collembola \\
\hline & Acariformes & Collembola \\
\hline 10 & Collembola & Collembola \\
\hline 11 & Collembola & Acariformes \\
\hline 12 & Acariformes & Collembola \\
\hline 13 & Acariformes & Collembola \\
\hline 14 & Collembola & Acariformes \\
\hline 15 & Collembola & Acariformes \\
\hline 16 & Collembola & Thysanoptera \\
\hline 17 & Collembola & Araciformes \\
\hline 18 & Acariformes & Collembola \\
\hline 19 & Diptera & Collembola \\
\hline 20 & Acariformes & Collembola \\
\hline 2 & Acariformes & Collembola \\
\hline & Acariformes & Collembola \\
\hline 23 & Acariformes & Collembola \\
\hline 24 & Collembola & Acariformes \\
\hline 25 & Collembola & Acariformes \\
\hline 26 & Collembola & Acariformes \\
\hline 27 & Collembola & Acariformes \\
\hline 28 & Collembola & Collembola \\
\hline 29 & Collembola & Thysanoptera \\
\hline 30 & Collembola & Acariformes \\
\hline 31 & Collembola & Acariformes \\
\hline 32 & Collembola & Collembola \\
\hline 33 & Collembola & Acariformes \\
\hline 34 & Collembola & Acariformes \\
\hline 35 & Collembola & Collembola \\
\hline 36 & Collembola & Collembola \\
\hline 37 & Acariformes & Collembola \\
\hline 38 & Acariformes & Collembola \\
\hline 39 & Collembola & Collembola \\
\hline 40 & Acariformes & Collembola \\
\hline 41 & Collembola & Collembola \\
\hline 42 & Acariformes & Collembola \\
\hline 43 & Collembola & Acariformes \\
\hline 44 & Collembola & Acariformes \\
\hline 45 & Collembola & Acariformes \\
\hline 46 & Acariformes & Collembola \\
\hline 47 & Collembola & Acariformes \\
\hline 48 & Collembola & Thysanoptera \\
\hline
\end{tabular}

\begin{tabular}{|c|c|c|c|}
\hline & May 2005 & August 2005 & October 2005 \\
\hline 1 & Nitidulidae & Araneae & Opiliones \\
\hline 2 & Nitidulidae & Hymenoptera & Carabidae \\
\hline 3 & Nitidulidae & Araneae & Opiliones \\
\hline 4 & Nitidulidae & Hymenoptera & Carabidae \\
\hline 5 & Elateridae & Scolopendridae & Chilopoda \\
\hline 6 & Nitidulidae & Araneae & Staphylinidae \\
\hline 7 & Nitidulidae & Siphonoptera & Chilopoda \\
\hline 8 & Collembola & Siphonoptera & Chilopoda \\
\hline 9 & Collembola & Hymenoptera & Araneae \\
\hline 10 & Nitidulidae & Diptera & Opiliones \\
\hline 11 & Nitidulidae & Hymenoptera & Nitidulidae \\
\hline 12 & Nitidulidae & Araneae & Araneae \\
\hline 13 & Staphylinidae & Orthoptera & Staphylinidae \\
\hline 14 & Homoptera & Acari & Carabidae \\
\hline 15 & Diplopoda & Araneae & Carabidae \\
\hline 16 & Diplopoda & Diptera & Carabidae \\
\hline 17 & Nitidulidae & Diptera & Chilopoda \\
\hline 18 & Nitidulidae & Araneae & Araneae \\
\hline 19 & Nitidulidae & Hymenoptera & Formicidae \\
\hline 20 & Anthomyiidae & Hymenoptera & Opilones \\
\hline 21 & Acari & Hymenoptera & Opiliones \\
\hline 22 & Araneae & Hymenoptera & Opiliones \\
\hline 23 & Nitidulidae & Orthoptera & Staphylinidae \\
\hline 24 & Opiliones & Diptera & Staphylinidae \\
\hline 25 & Nitidulidae & Araneae & Staphylinidae \\
\hline 26 & Nitidulidae & Araneae & Diplopoda \\
\hline 27 & Nitidulidae & Siphonptera & Formicidae \\
\hline 28 & Mycetophilidae & Siphonptera & Araneae \\
\hline 29 & Anthomyiidae & Siphonptera & Opilones \\
\hline 30 & Formicidae & Araneae & Opilones \\
\hline 31 & Araneae & Araneae & Opilones \\
\hline 32 & Nitidulidae & Araneae & Carabidae \\
\hline 33 & Nitidulidae & Araneae & Carabidae \\
\hline 34 & Nitidulidae & Orthoptera & Carabidae \\
\hline 35 & Nitidulidae & Orthoptera & Formicidae \\
\hline 36 & Nitidulidae & Siphonoptera & Formicidae \\
\hline 37 & Carabidae & Araneae & Formicidae \\
\hline 38 & Diplopoda & Diptera & Opiliones \\
\hline 39 & Nitidulidae & Hymenoptera & Opiliones \\
\hline 40 & Nitidulidae & Siphonoptera & Opiliones \\
\hline 41 & Nitidulidae & Diptera & Opiliones \\
\hline 42 & Nitidulidae & Hymenoptera & Carabidae \\
\hline 43 & Nitidulidae & Siphonoptera & Carabidae \\
\hline 44 & Nitidulidae & Orthoptera & Carabidae \\
\hline 45 & Nitidulidae & Araneae & Staphylinidae \\
\hline 46 & Nitidulidae & Siphonoptera & Staphylinidae \\
\hline 47 & Nitidulidae & Araneae & Staphylinidae \\
\hline 48 & Nitidulidae & Diptera & Staphylinidae \\
\hline
\end{tabular}

